\title{
SHE SUFFERED FOR CHRIST JESUS' SAKE
}

\section{The Scottish Covenanters' emotional strategies to combat religious persecution $(1685-1714)^{*}$}

\section{Dolly MacKinnon}

UNIVERSITY OF QUEENSLAND

In the winter of 1704 at the Presbytery Kirk Session in the town of Wigtown in Galloway, Baillie M'Keand addressed the minister, Mr. Thomas Kerr, and all those present at the kirk. ${ }^{1} \mathrm{He}$ was burdened by his past. His involvement in a particular egregious event in May of 1685 at the height of what the Presbyterians termed the 'Killing Times' in Dumfriesshire and Galloway in Scotland weighed heavily upon his conscience. The names of those executed were Margaret Wilson, Margaret Lachlane, William Johnston, John Milroy, and George Walker. ${ }^{2}$ Although none of them were Wigtown parish inhabitants, they were remembered by members of their trans-generational community for having been executed there on 11 and 12 May $1685 .{ }^{3}$ Alexander Shields depicted the two women in the frontispiece image of his book A Hind Let Loose (1687). The emotional memories of these summary executions, and the practices of remembering performed by the surviving trans-generational members of the community were driven by their deep sense of trauma and loss, their hope for a reformation yet to come, and an abiding reverence for those martyred. By 1714, funeral monuments had been erected in the Wigtown kirkyard to the women and men executed nearly thirty years earlier, publicly claiming their martyrdom.

* This research was funded by the Australian Research Council Centre of Excellence in the History of Emotions, Europe 1100-1800 (CE110001011) through my Associate Investigator Grant (2011-2014), 'Emotional Landscapes: English and Scottish Battlefield Memorials 1638-1936', and my collaborative Australian Research Council Discovery Grant (DP140101177), 'Battlefields of Memory: Places of War and Remembrance in Medieval and Early Modern England and Scotland' (2014-2016). The research was conducted as part of my Visiting Fellowship at the Institute of Advanced Studies in the Humanities, The University of Edinburgh, in early 2016, and my Visiting Fellowship at the School of Divinity, The University of Edinburgh, in early 2018. 
Before the assembled gathering in 1704, M'Keand addressed the 'session for the privilege of the sacrament which had been denied him these past 19 years'. He was 'declaring his grief of his heart that he should have sitten on the sieze of these women who were sentenced to die in this place in the year $16855^{5}$ The women, known as the two Margarets, one aged 18 and the other about 60, had refused to take the test of the Oath of Abjuration. This oath was used by authorities to enforce religious conformity. It required Covenanters-adherents and signatories of the National Covenant of 1638, and the Solemn League and Covenant of 1641/42 in support of a Presbyterian form of church government-to renounce the supremacy of King Jesus by recognising Charles II's authority as the king of the church and state in Scotland, as well as labelling those Covenanters, who had killed Archbishop Sharp of St Andrews in 1679, as murderers. The Wigtown women refused to take the oath, and they were sentenced to death. The women were tied to stakes within the tidal flood of the river and were drowned. According to the Wigtown kirkyard monument, on the following day three men were publicly hanged for the same offence.

Therefore, while M'Keand named the death of the women, and sought redress from his kirk community, his address did not specify the nature of his involvement in the women's death. Instead, he stated 'it had been frequently his petition to God for true repentance and forgiveness for that sin'. ${ }^{6}$ For M'Keand his involvement in the death of the women created emotions of sorrow, regret, and unworthiness over time. This sense of sin had prevented his taking the sacrament with his community. The archive does not record whether his exclusion from the sacrament was a decision of the kirk community or was self-inflicted. Significantly, M'Keand makes no mention of the men who were executed on the following day in his emotional petition to God, only referring to his emotional state regarding the women. No archival records survive regarding the men, and we have no way of knowing if (or how) M'Keand was involved. The Presbytery Kirk Session heard M'Keand's address and decided to discuss the matter further, asking him to withdraw from the session. With M'Keand no longer present, the assembled kirk session set to 'enquiring into this affair and the carriage of the said bailie since that time [1685]'. Precisely what was said is not recorded. However, on being asked to return to the session, and 'being satisfied with his [M'Keand's] conversation since, and the present evidence of repentance now, they granted him privilege' once more to take the sacrament. ${ }^{7}$ Before the gathering, M'Keand was 'admonished, and exhorted to deliberation, due to [the] tenderness in such [a] solemn address unto God'. 8 The kirk community appraised the supplicant's application and emotional states over the period since the events of nineteen years earlier. Through this process and the evidence of his grief, M'Keand was able both to seek and be granted atonement and re-entry into his spiritual community.

Those assembled at the Wigtown Presbytery Kirk Session that day were well acquainted with what had happened in 1685. For example, Patrick M'Kie was the son of Katherine Lauder who had confessed to withdrawing from the episcopal kirk between 1682 and 1684 and who had been fined $£ 250$ [Scots] as 
a result of her spiritual defiance. ${ }^{9}$ The nonconformists in the region had experienced punitive fines and summary executions, only some of the myriad forms of persecution they suffered. Their suffering also included the quartering of troops with nonconformist families, which proved a physical hardship, fiscal privation, and spiritual trial. These were all powerful mechanisms used by the crown in an attempt to stem and intimidate Covenanter communities, and those associated with them, in what the authorities saw as a tide of religious rebellion against Episcopal Church government and the divine right of the king in Scotland. M'Keand, having been a part of this process for the crown in sentencing these women to die, was, in turn, attempting to make peace with his own emotional trauma. He articulated as much to the kirk session, as his actions were driven by the 'grief of his heart' regarding his involvement 'in the sieze of these women who were sentenced to die in this place in 1685 '. ${ }^{10}$ M'Keand's emotional account is the only surviving archival trace written from the perspective of a perpetrator and displays the strong emotions generated by direct involvement in the events at Wigtown. The women's Wigtown kirkyard monument also lists four male perpetrators associated with the women's executions: 'Lagg, Strachan, Winram and Gr[a]hame'. ${ }^{11}$ Although the emotional responses of these men to the women's deaths are not recorded in the archives, the increasing humiliation felt by authorities, generated by their failure to quell the rebellion, must have played some part in the actions they took when the rebels were captured, tested, and then summarily executed.

In the years leading up to the Killing Times, the authorities in Western Scotland had actively sought to drive out nonconformity. For example, when Sir Andrew Agnew, the Sherriff of Galloway, had refused to take the test, he was deprived of his office, which was then bestowed upon John Graham of Claverhouse on 19 January 1682. Claverhouse was known simultaneously as 'Bonnie Dundie' and 'Bloody Clavers', representing the views of him by heterotopic emotional communities at this time. ${ }^{12}$ His brother David Graham was appointed conjoint Sherriff on 12 May 1682. Two months earlier, in Wigtown on 5 March 1682 Claverhouse had written to the Marquis of Queensbury about his frustration at the rebels:

Here, in this shire, I find the lairds all following the example of a late great man and considerable heritor among them; which is to live regularly themselves, but have their houses constant haunts of rebels and intercommuned persons, and have their children baptized by the same, and then lay all the blame upon their wives. But I am resolved the jest shall pass no longer here, for it is laughing and fooling the Government. ${ }^{13}$

With the growing hard-line implementation of summary executions, nonconformist women, children, and men increasingly fell foul of the authorities during the 1680 s, and the emotional stakes on both sides of the conflict continued to escalate. 
The existence of the two female and three male Wigtown martyrs has courted controversy, but only in the case of the two women. There is a tacit presumption that men die in conflicts. These women, however, have been commemorated, their existence contested, even categorically denied and recast as part of a fictitious Presbyterian martyrology from 1687 onwards. ${ }^{14}$ Both the women and men were tried because of their nonconformist religious views, resulting from their collective emotional acts of defiance that had set them at odds with the church and state, with fatal consequences. I will leave aside certain traditional debates that claim the women did not exist, because they sit within a much broader debate about historiographical approaches, the place of winners and losers in history, and historical narratives that actively exclude or include women from accounts of the past as communicated in the present.

As historians, we too have our own conscious and unconscious biases encompassed within our emotional language, historical focus, description, and analysis. Our choice of narrative reflects our unintentional and unacknowledged enthusiasm for a particular approach. As such, we need to recognize the peculiarities of our own emotional language and approaches as historians. We need not only acknowledge but also articulate what I will term here as our own emotional blind biases. Therefore, the archives of that past must be examined for all the traces they reveal, and not just for those which historians consciously or unconsciously choose to include, ignore, or exclude. This then enables us to ask different questions of the extant archives in order to concentrate on the power of the language of emotion to drive action and on the ways emotions can be found in the surviving evidence trails (text, objects, landscape) that communities leave behind. For the emotional Covenanter community within Scotland in the late seventeenth and early eighteenth centuries, martyrdom was part of the sacrifice for King Jesus. Emotions also drove the creation and implementation of laws to combat and quell this rebellion. The resulting summary executions the legislation enabled were perceived by those who wrote the laws, those who then enabled them, and those who implemented them as the righteous legal actions of men and women in support of the state and church of Charles II.

Therefore, the surviving material evidence of acute emotional events like the Wigtown executions in a persecuted Covenanter community did not always include direct written testimony. The Covenanters' emotional responses demonstrated the existence of this trans-generational community and the accompanying practices of perpetuating memories. Every generation, through their own practices of marking, commemorating, educating, and remembering, attempts to perpetuate the meaning of events in the new context of the generations that follow. The Covenanters created a virtual community through print and specific touch points of memory and memorialization through the physical sites of execution and the emotional texts on the memorials they erected. As Monique Scheer states, this occurs in communities because they 'make use of the capacities of a body trained by specific social settings and power relations' ${ }^{15}$ Covenanter communities considered the fear and joy of suffering and martyrdom central to their 
communal experience and identity and used specific words such as 'martyrdom' and 'reformation' to drive and maintain the emotional quality of their texts.

Pivotal to this Covenanter community are Scheer's four types of emotional practice: mobilizing, naming, communicating and regulating emotion. All are recoverable in the surviving evidence of Covenanter activities, ranging from their clandestine religious meeting places in the hills, the dynamic nature of the creation and updating of printed accounts of the last testimonies of their martyrs, and the practice of erecting monuments using the language of the martyrs' suffering and the hope of a reformation to come in their incised texts. These are examples of Scheer's contention that 'emotional arousals that seem to be purely physical are actually deeply socialized'. ${ }^{16}$ A godly community, such as the Covenanters, thrived on their zeal in the quest for an ongoing reformation and their joy at acts of martyrdom. Furthermore, their process of collecting memory and remembering was driven by their religious persecution. These communities experienced a cycle of different emotions that nurtured and drove them on in their quest for reformation; these emotions ranged from a fear of death to a reverence of death to a joy of martyrdom. They exemplify Scheer's thesis 'that this feeling subject is not prior to but emerges in the doing of emotion'. ${ }^{17}$ The individual is part of an emotional community, and as such is immersed in its physical and linguistic practices. These communities then, in Barbara Rosenwein's sense, are ones where emotions, the mind, and body function as 'a locus for innate and learned capacities deeply shaped by habitual practices' ${ }^{18}$

An emotional community comprises trans-generational members, and the actions of each generation works towards the attainment of future changes over time in different ways. When direct memory fails, then those generations that follow actively remember, retell and narrate the past within the new context and concerns of their present. Therefore, the two women and three men publicly executed in Wigtown demonstrated the real emotional power of their decision not to take the Oath of Abjuration. Their actions were driven by religious dissent, as well as by their preparedness to die for their beliefs and community as martyrs. It also demonstrates the involvement of godly women, men, and children in Dumfriesshire, Galloway, and beyond in Scotland, caught up in a violent and bloody period during the religious wars of the late seventeenth century. The emotional impact of these acts of martyrdom echoed into the following centuries.

The Covenanters were the adherents and signatories of the National Covenant (1638) and the Solemn League and Covenant (1641/2). These agreements that were signed by kirk congregations, some of them in blood, supported the establishment of a Presbyterian church throughout not only Scotland, but also England that would do away with bishops and the episcopal form of church government. While many in Scotland and England had adhered to these covenants, by 1650 the covenanted citizen's experience of the actuality of that spiritual triumph in church government would prove fleeting. ${ }^{19}$ The Restoration of Charles II in 1660 saw the established church in Scotland lurch back to 
episcopacy (that is, to church government through the rule of bishops by Statute) in 1662. The Covenanters, also known as the Societies, were now branded nonconformists, who in turn, were set on their own aim of completing what they now saw as the incomplete reformation of the Church of Scotland. Their ongoing struggle was to reinstate the Presbyterian form of church government. The Covenanters found their loyalty challenged and their faith and religious worship tested. Driven out of their parish kirks, they worshipped in clandestine conventicles held in the open, in all seasons, on the hills and moors from c.1662 onwards. First under Charles II, and then James VII \& II, a Covenanter's individual adherence was to King Jesus, rather than to the crown. They refused to take the Oath of Abjuration, which required every individual to swear allegiance to the king as head of the church, and his institution of an episcopal kirk within Scotland. Instead, fuelled by their belief in the covenants they had signed, they renounced both king and episcopal kirk in favour of their radical field preachers and declared the supremacy of King Jesus over all forms of manmade government, both state and church.

The radical nature of the Covenanters' pursuit of a return to a covenanted Scotland is evident in the crown's emotional language used against them in the Oath of Abjuration, intended to pull all dissenters into line and ultimately into conformity. If apprehended, women, men, and children were asked to take the test oath:

I, A.B., doe hereby abhorre, renounce, and disowne in presence of the Almighty God the pretended declarations of warr lately affixed at severall paroch churches in so far as it declares a warr against his sacred Majesty and asserts that it is lawfull to kill such as serve his Majestie in church, state, army or country. ${ }^{20}$

The telling point for the government centred on the emotional words they used in the Oath of Abjuration, such as 'abhore' and 'disowne', as well as labelling the Covenanters' public claims as 'pretended declarations'. Conflicting emotionally charged and laden terms were also used to describe the death of Archbishop James Sharp, Chaplain to Charles II, who in 1661 was consecrated Archbishop of St Andrews (1618-1679) and was a fierce detractor of the Presbyterians. Sharp had survived an assassination attempt by James Mitchel on 11 July 1668 in Edinburgh, for as Archbishop Gilbert Burnet recounted, 'Sharp was so universally hated, that, tho' this was done in the full day light, and on the high street, yet no body offered to seize the assassin'. ${ }^{21}$ But in May 1679, he was pulled from his carriage at Magnus Moor near St Andrews by a band of nine Covenanters from Fife, comprising 'two lairds, a weaver, and six tenant farmers'. ${ }^{22}$ Sharp was 'shot and stabbed ... to death before his own daughter Isabelle's eyes' ${ }^{23}$ This event was understood and interpreted by the state and the Covenanters in opposing ways: for the government it was considered the murder of 'such as serve his Majesties in church, state, army or country'; while the 
Presbyterian Covenanters saw it as a lawful killing, a just act under God's law rather than man's law, in the ongoing struggle and quest for a return to a covenanted church government that may take generations to achieve.

Part of the strategies used by the crown in creating these acts of exclusion was the emotional language they used in drafting this legislation. Perplexed, John Livingston in 1671 claimed 'It is not now Episcopacy and Ceremonies, that is the Controversie', but rather, 'whether Jesus Christ be King of this own Church ... or if the Leviathan of the Supremacy shall swallow it all up'. ${ }^{24}$ As the twentieth-century historian, and Scottish nationalist, Agnes Mure Mackenzie concluded:

The whole 'Killing Time' turns on that Oath [of Abjuration]... All through the winter of 1684-5 this state of things sprawled and smouldered in the South-West [of Scotland]. Then on the $5^{\text {th }}$ February Charles II died, and the throne of the three kingdoms passed for a brief while to his brother, James, Duke of Albany and York [James VII \& II], a Catholic, as firm as [the Covenanter James] Renwick [executed in 1688] in his own creed [by fixing his declaration to church doors]. As accessions go, it was not an auspicious one. ${ }^{25}$

After the death of Charles II, and then during the reign of his brother, the openly Roman Catholic James VII \& II, the Scottish Covenanters were subjected to waves of religious persecution, discrimination, and banishment, each re-enforced with renewed vigour and viciousness, and the practice of summary executions; many witnessed by the eyes and ears of their trans-generational families. The arrival of William of Orange did nothing to stem this violent discrimination in pre-1707 Scotland. The Covenanters in Scotland and in exile remained a revered, reviled, and persecuted minority, who in turn remained resolute in their endeavours, as Christian soldiers, to complete the unfinished business of the Calvinist Reformation. For King Jesus to ultimately triumph in a global project for their religious freedom, the Covenanters concluded that the religious battleground of Scotland must first be won. Their actions were increasingly met by the state with punitive acts designed to subjugate and displace them, acts that required the ultimate tariff, that of human life, for any breach. The Scottish Calvinist communities in exile across Europe provided the emotional bedrock for those of their brethren still in Scotland. The Covenanters incurred corporeal acts of legal torture, branding, summary execution, or banishment to the plantations and colonies of Jamaica, Barbados, and Virginia.

The events leading up to the executions at Wigtown over two days in May 1685 reflect the heightened emotional stakes on both sides: for the persecuted and excluded and for those that created and then implemented the ecclesiastical and legal framework for that religious conformity and the accompanying acts of execution. Certain words were used to label and stigmatize both Covenanter societies and their individual members. The reality of this legislation was 
that it not only excluded people from their emotional attachments to the realm, but also created conflicting emotions within their economic, social, familial, as well as spiritual communities, and the testing of their loyalties. It is important to note here that not every Covenanter chose the joy of martyrdom and King Jesus over their own sense of fear, self-preservation, and self-interest, often to the cost of other members of their community.

Equally, the responses to this legislation by the Covenanters faithful to their cause deployed emotional language of their own as part of the strategies that enabled them to create a counter-culture. Their community and spiritual worship survived, through God's will, beyond the boundaries of the kirkyard, in their clandestine meetings held in private homes or out of view on the open hillsides. Both the church and state, and the Covenanters embroiled in this violent conflict, held a staunch belief that God was on their respective sides. Both the crown and the Covenanters believed theirs was the only true path to godly worship. What is more, each side believed that God sanctioned their actions, even when they moved into the realms of killing as acts of holy violence.

On 23 April 1685, only weeks before the events at Wigtown in May 1685, an Act Against Preachers at Conventicles and Hearers at Field Conventicles proclaimed that 'Our soveraign lord, considering the obstinacy of the fanatical party who, notwithstanding all the laws formerly made against them' took further legal avenues to stem their rebellious tide. For the Covenanters did 'persevere to keep their house and field conventicles, which are the nurseries and rendezvouzes of rebellion'. The Government feared the trans-generational nature of this rebellion with the radical Covenanters being perceived as ranging in age from the very young to the very old. Left with no option, 'therfor his majesty, with consent of his estates in parliament, doth statute and ordain' this act. The emotional heart of this act was 'that all such as shall hereafter preach at such fanatical house or field-conventicles ... as also such as shall be present as hearers at field conventicles, shall be punished by death and confiscation of their goods'. ${ }^{26}$ Such legislation engendered extreme emotional responses, such as the prospect of a joyous martyrdom by those condemned to die and the possibility of exacting vengeance by those who enforced it.

Archibald Campbell, ninth Earl of Argyll, who was executed on 30 June 1685, demonstrated in his speech on the scaffold the emotional script of martyrdom to be followed, and as found in the myriad printed pamphlets purporting to contain his final words. Argyll railed against those who were 'chusing sin rather than sufferings, and a short life with eternal Death rather than Temporary Sufferings with a Crown of Glory'. ${ }^{27}$ What is more, Campbell continued:

at my death I would pray that there should never want on[e] of the Royal Family to be a Defender of the True, Antient, Apostolick, Catholic, Protestant Faith, which I now do; and that God would enlighten and forgive all of them that either hid in Error, or have shrunk back from their Profession. ${ }^{28}$ 
But while Campbell's course was run, 'in all Events' he did 'pray God may provide for the security of his Church, that Antichrist nor the Gates of Hell may not prevail against it'. ${ }^{29}$ Campbell's speech was printed, and those who did not witness his execution in person could then read, or hear read aloud, the love and hatred from his printed speech. The emotional ways in which his script was read produced either joy or loathing in turn.

On 16 July 1685, A Proclamation, For a Thanksgiving Throughout the Kingdom of Scotland, for the Late Defeat of the Kings Enemies was made. This was in response to the deaths of 'James Scot late Duke of Monmouth, and Archibald Campbell late Earl of Argile' who 'with Traiterous Confederates and Accomplices ... invaded both Our Kingdoms of Scotland and England by Armed Force'. Their 'purpose [was] to have destroyed Us, and all Our good and Loyal Subjects, and subverted Our Government in Church and State'. The emotional rationale for this day of thanksgiving was contained within the proclamation: for 'it having pleased Almighty God (by whom Kings Reign, and Princes decree Justice) by his Miraculous Providence and Omnipotent hand...[to] confound and blast Hellish Devices and Projects of these our Enemies, and utterly to discomfite and subdue them'. It was precisely because of 'a Due and Religious sense of Gods so great Mercy and Deliverance towards us, and Our People in these Realms, Thought fit ... to set apart solemn days of Thanksgiving'. The purpose was clear 'for offering solemn Praise to Almighty God ... that his Divine Majesty may continue his undeserved Goodness towards Us... ${ }^{30}$ Each side involved in this battle understood the outcome as a demonstration of God's bounty towards them or as a lesson to urge repentance and begin a godly life anew.

Emotional communication practices are evident in the Covenanter archives and surviving material culture. The community mobilized to find safe, clandestine places of worship. In the face of death, the executed Covenanter martyrs regulated their emotions by placing great importance on the words of their final public testimonies. These testimonies were in turn collected, printed, disseminated, and reiterated amongst their communities, first, in 1667 in Naphtali, or The Wrestling of the Church of Scotland for the Kingdom of Christ Contained in a True and Short Deduction Thereof, from the Beginning of the Reformation to Religion, Until the Year 1667. Together with the Testimonies of Some Who Have Died for the Truth Since the Year $1660 .{ }^{31}$ The trans-generational intention of this work is evident in its title, for this collection took its name from Naphtali, which was Hebrew for my struggle and my strife. Naphtali was also the name of one of the sons of Bilhal, whom Rachael gave to her husband in order to produce children and heirs and one of the twelve tribes of Israel in the Old Testament. As the persecution of the Covenanters continued, Naphtali was republished with new testimonies added over time. This was the emotional work of a trans-generational community driven by their perceived need for this ongoing reformation, a work still in progress.

The response of the crown to such publications was swift. On 12 December 1667, in order to combat 'a most treasonable and seditious pamphlet, 
entitled, Naphtali; Or the Wrestling of the Church of Scotland, lately imported, vended and dispersed within this kingdom', all copies were to be surrendered to the sheriffs or deputies of each shire and then transferred to the Clerk of the Privy Council by 12 January $1667 / 8$. Anyone caught with a copy of this text after this date, was to be fined 2000 pounds of Scots money, and be subjected to the punishments for the printing of seditious materials. Those copies that were confiscated were to be 'publically burnt in the high street of Edinburgh, near to the Mercat-Cross thereof, by the hand of the hangman'. The printing and publishing of this order by the king's printer therefore allowed 'none to pretend ignorance'. 32 The vengeful and punitive actions of the crown were driven by a fury and fear of what was understood as ongoing religiously inspired acts of treason and sedition in Scotland. The crown called these trans-generational religious gatherings 'conventicles' and 'nurseries and rendezvouses of rebellion'; the Reverend Alexander Shields considered them 'nurseries of zeal and godliness'. 33

For the Covenanters, like the mid-seventeenth-century Royalists and Regicides before them, exile and banishment stretched, but did not break, the emotional bonds of these communities. Their emotional actions revealed emotional strategies that were deployed to create a cohesion of emotions based on action words, such as suffering, persecution, burden, martyrdom, hope, thanks, reformation, and covenant. Some of these emotional action words, such as 'grief, were used simultaneously, by multiple and even opposing communities, while certain words set those communities apart. What we have then are events that are bound up with emotions.

The events of 1685 generated, for the Covenanters, a sequence of contemporary documentation and material culture that in turn fits within the dynamic process of emotional communities dealing with violence, suffering, trauma, and its aftermath. Within this timeframe then there is evidence of communities recognizing these emotional acts, creating a minimalist narrative framework in which to articulate the existence of that violent event. Then a space for collective suffering endured by these communities over time is acknowledged, recognized, articulated, renovated, and revitalized with new emotional scripts and actions from the growing number of sufferers. Each new emotional act provides a didactic text or object of interpretation for the following generations. The transmission of events from memory to remembering required these emotional acts to be recorded and re-enacted through emotional scripts such as the last testimonies in Naphtali, or at the very least, an acknowledgement that each death had occurred and was committed to memory and then retold.

While the crown could control the kirk, and regulate those who preached there, it could not control the conventicles that had sprung up in response to what many considered unacceptable church doctrine. Held in the hills beyond the kirkyard, they remained there under threat of discovery and reprisal. These communities may have been small, but they had a disproportionate influence on other like-minded Covenanters, for this emotional community's spiritual goal 
usurped any obligations they perceived they had to king and country. The trans-generational nature of this process is also central to consider, for the course taken by the young in communities in Western Scotland, may either have adhered to, or differed greatly from, the projected spiritual path set out for them by their parents and elders.

The material survival of a battered field Bible demonstrated for the Covenanters the emotional actions of their God-given resilience in the face of persecution. This was experienced by the women, men, and children that assembled illegally to worship King Jesus. They risked paying a very high penalty if they were discovered. For example, the damaged seventeenth-century Bible of field preacher, William Hannay of Tundergarth, Dumfriesshire, is held in the National Museum of Scotland Covenanter Permanent Exhibition. The accompanying NMS exhibition card states the following:

Hannay was hiding in straw in a barn when government troops approached. He escaped to the hills but left this Bible behind and later returned to find it damaged by a sword cut. ${ }^{34}$

The Bible had been handed down through generations, as a holy relic of the Church of Scotland, and as an example of God's mercy, for the owner of the Bible had escaped unharmed. ${ }^{35}$ The violence exacted upon the Bible by the trooper in turn demonstrated his own emotional response in finding that his rebel quarry had escaped him, unharmed. This form of material culture evidence was read by the Covenanters as a sign of God's intervention in the everyday life of a godly individual.

In early modern Germany, as Susan C. Karant-Nunn has observed, sharing in the suffering of Christ was a journey for the imagination. ${ }^{36}$ For some Covenanters in Scotland, however, suffering and even martyrdom were practical realities, where emotional scripts were played out and then retold with additional layers of emotional rhetoric by the generations of family and friends that followed them. What was graphically and confrontingly real for those who had actually attended and witnessed these public executions was then carried in the traumatic memory, conversations, and silences about these events amongst those that lived on. Each generation elaborated these accounts with the express purpose and through the evolving emotional scripts they deployed, of stirring the imagination of Christ's suffering and martyrdom within the godly.

The oral testimony of Helen Alexander (c.1653/54-1729), privately printed by her family in the mid-nineteenth century as Passages in the Lives of Helen Alexander and James Currie of Pentland (Belfast: privately published, 1869) reveals the scripts followed by women such as her. Helen Alexander had been a committed member of James Renwick's conventicle during the 1680s. As David Mullen has argued, that commitment brought her perilously close to the gibbet. $^{37}$ Alexander recounted the events surrounding Renwick's execution: 'And when Mr-Renwick was execute [in Edinburgh on 17 February 1688], 
I went and saw him in prison'. The recounting of the emotional acts of the sufferers included their emotional script. On visiting Renwick prior to his execution, Helen Alexander said to him, "Ye will get white robes"; and he said, "And palms in my hands", referring to a verse from Revelations. Alexander continued: 'when he was execute, I went to the Greyfriar's Yard, and I took him in my arms till his ... clothes were taken off, and I helped to wind him before he was put in the coffin'. ${ }^{38}$ Renwick had, within God's company, suffered martyrdom. Alexander's sufferings, perseverance, and progress through life was judged by her to be the result of God's intervention:

And I had a long fever; but my lord, that many a time brought me through, brought me through at this time, for which I bless the Lord. It was for his sake I suffered that and many other things; but my soul had cause to bless the Lord that he was aye with me in all my trials. ${ }^{39}$

Helen Alexander and her husband James Currie would later erect a funeral monument to the Covenanter martyrs in Greyfriars kirkyard in Edinburgh in 1706.

Within this emotional community, defined neither by geographical nor political borders, God's presence in the Covenanters' lives persisted. The suffering endured by them was seen as part of God's purpose; even if the ultimate cost was death, there was the certainty of salvation. As Alec Ryrie has concluded, 'Protestants' despair was rooted in their almost narcissistic concern with their own spiritual well-being. ${ }^{40}$ But as Ryrie explains, that narcissism was symptomatic of early modern Protestants who 'paid such close attention to their emotions', because 'they expected to meet God in them. Emotion was a form of revelation'. ${ }^{41}$ Therefore, the emotional burden of a martyrdom suffered for King Jesus placed those self-assessing Protestants well up the ladder of the godly elect and demonstrated to others a path to salvation. The printed accounts of the last testimonies of the Covenanter martyrs served a dual function: to record the events and accounts offered during their suffering and to provide a didactic text through which emotional scripts for men, women, and children were rehearsed and retold to following generations by those who survived. These texts coexisted with the emotional actions and scripts disseminated by word of mouth and provided an emotional ballast to those persecuted communities within Scotland, as well as in England, Ireland, and other places of exile. Print was the technology that easily disseminated dissenting Covenanter claims or what the crown termed seditious views. Print, unlike human bodies, could not be curtailed by geographic or social boundaries. Once read, the memory of that text could not be entirely removed, even by public acts of burning by the hangman's hand. Print provided an intangible intellectual space and theological place in a godly firmament for a community of saints and sufferers, in which to commune while experiencing physical depravations.

The Covenanters, as a trans-generational community, clearly viewed their emotional experiences as a way of revealing and analysing God's work in 
their everyday lives, especially during times of great personal trial or triumph. Beyond the printed text of the Holy Scripture, God also spoke directly to the godly in order to guide daily life as an interior voice, within and apart from their physical world yet acting as a bridge between the individual spirituality of the believer and King Jesus. When the journal of Archibald Johnstone of Wariston reflected on the sudden death of his wife, Wariston mapped out 'his grief, proclaiming in the context of his own emotional turmoil, 'Lord, I sould <sic > preferre thy glory to my salvation'. As Ryrie notes, this grief was countered by the 'influx of extraordinary spiritual comfort and confidence' Wariston experienced, that led him immediately to conclude the certainty of his own salvation. ${ }^{42}$ That the Covenanters were the elect was an overriding belief for every generation.

In the twenty-first century, landscape evidence of the events of 1685 in Wigtown still lie marked by a heritage trail to the martyrs of the Killing Times. The Wigtown martyrs' monuments and pilgrimage trail demonstrate how, over time, the ongoing memory of these events were transformed into communal expressions of remembrance and forgetting, by actively re-inscribing this emotional landscape after the initial violent events. By the nineteenth century, the rehabilitation of the Covenanters occurred after the fracture of the Church of Scotland following the Disruption of 1843 and with the aim of helping to create a Scottish identity. James J. Coleman has discussed how from the nineteenth century onwards 'different localities within Scotland invoked covenanting memory as a means of celebrating their own contribution to Scotland's nationality' for the express purpose of defining Scottish identity and nationalism in their present. ${ }^{43}$ Gordon Pentland has analysed this practice in the reform politics of nineteenth-century Scotland. ${ }^{44}$ Covenanter memorials have also been the subject of concerted cataloguing, most recently in the twentieth century in Thorbjörn Campbell's Standing Witnesses: An Illustrated Guide to the Scottish Covenanters (1996). ${ }^{45}$ Magnus Magnusson described these memorials as 'sad, proud and often neglected monuments and headstones all over Scotland commemorating the martyrs to the Covenant during the "Killing Time" of $1685 .{ }^{46}$ Initially, these highly emotional events occurred within the context of an unfinished religious war. In the centuries following, when monuments were erected, that historical past was then purposefully written by members of this trans-generational community, as a narrative of the pre-history to the present. However, it was now being used in a very different historical context and for different purposes after the Church of Scotland Disruption of $1843 .^{47}$

What we have here then are emotions as drivers of social, political, cultural, and religious change and conflict. Simultaneous emotional communities (Episcopal and Covenanter) exist in open conflict, with the power of government and monarch holding sway over what can and will be publicly commemorated, as well as how this is to be done. The persecuted communities then take to print, and later to memorial inscriptions, to record their place in this emotional landscape of religious conflict. Helen Alexander reflected as 
she was 'interrogate by Sir William Patterson, a Clerk of the Privy Council' about whether Andrew Gulon had come 'to my house'. 'He asked if any vagabonds came to my house, and I said, "No" (for so they termed these sufferers)'. 48 The oppositional terms used to describe Andrew Gulon demonstrate the emotion behind the use of each word, for Sir William Patterson's vagabonds were Helen Alexander's sufferers. In order to analyse this fracture point I have focussed upon historical moments and data related to contentious acts of summary execution. Words and deeds then become heterotopic signatures upon an emotional landscape that is simultaneously national, nonconformist, familial, traumatic, and victorious.

These emotional acts are part of the emotional dialogue generated by these trans-generational communities. For those women, men, and children present at these events are also the keepers of the material culture evidence of suffering and are responsible for the recollection and retelling of their emotional personal narratives. Their emotional-language infused actions were used over time as a litmus test against which the realities of their present were measured and mediated by their temporality.

This analysis has raised important additional questions for future research in the history of emotional actions. Firstly, we need to consider the age of the protagonists involved in these events, the significance of gender as well as the social and cultural sorts of people that appear or are removed from traditional historical accounts. Do the registers of emotion that we recover and calibrate through textual analysis conform to what we know about the emotional capacities of persons of that age, gender, and social status in these past societies? As historians, we are bonded labourers to the past. But the subjects of our research are caught in their present. The inevitability of what will transpire for them is not available to them in its entirety. Their knowledge of the emotional actions of suffering and martyrdom are driven by their fluid emotions - such as fear, hope, despair, or disbelief. Secondly, our own emotions as historians writing about these events may in turn be tinted by knowledge of the horrific inevitability of what we know will actually play out. As historians, we cannot unknow the sequence of known events from the past, nor can we forget them. Emotions are embedded in what historians choose to say, how they say it, where they recount these stories, as well as whether they choose to withhold their speech and remain silent about the past. Therefore, spaces, places, texts, memories, and objects are repositories of emotional acts that historians either purposefully acknowledge or wilfully disregard.

Finally, the recognition that places of execution/murder create a contested heterotopic emotional landscape is important to remember and acknowledge. Such sites of suffering are sites of emotional acts, spaces for the existence of conflicting memories, and opposing processes of remembering. By banishing those captured Covenanters from Scotland's shores to the Americas and the Caribbean, the crown attempted to physically remove the threat of further rebellion. But in doing so they also removed those individuals from their physical, spiritual, economic, social, and 
emotional landscapes and either greatly diminished or exiled those communities. For those who remained spiritually and culturally banished within their own landscapes in Scotland, their survival was a waiting game, driven by the hope achieved from continuing to hold covert and clandestine meetings of the faithful undetected. The blood of martyrs nourished not only that landscape, but also the imagination, offering succour to the spiritual and emotional needs and actions of those transgenerational Covenanters who remained alive. For those in every generation who lived on into old age, hope and joy continued to support them, sustaining their struggle for a completed reformation for King Jesus's sake.

\section{Notes}

1 Minutes, Presbytery of Wigtown, 8 July 1704, CH2/374, National Records of Scotland (hereafter NRS).

2 Lachlane's name could also be spelt McLaughlin, McLuachlison, and Lauchlison.

3 Robert Wodrow, The History of the Sufferings of the Church of Scotland from the Restauration to the Revolution, 2 vols (Edinburgh, 1721); J. Thomson, ed., A Cloud of Witnesses (n.p., 1871); Sharon Adams, "Wilson, Margaret (1666/7-1685), alleged covenanter martyr," in Oxford Dictionary of National Biography (hereafter DNB) (Oxford: Oxford University Press, 2004), https://doi.org/10.1093/ref:odnb/29677, states: 'The story of the Wigtown martyrs, as the two Margarets became known, is a crucial component of the covenanting martyrology and, as it involved the execution of women, a source of controversy which provoked later debate as to whether or not the executions were carried out'. Timothy D. Barnes, Early Christian Hagiography and Roman History (Tübingen, 2010), 325-28. There is also much debate about the writing out of the Covenanters in Scottish history. "Wigtown's Heritage," created in 2004, accessed 2 May 2013, http://freespace .virgin.net/harold.hall/angchurch.htm

4 Minutes, Presbytery of Wigtown, 8 July 1704, CH2/374, NRS.

5 Kirkinner and Penninghame statements read and sanctioned, 27 February 1711, quoted in Archibald Stewart, History Vindicated in the Case of the Wigtown Martyrs (1867; repr., Edinburgh, 1869), 95.

6 Session Book/Minutes, Presbytery of Wigtown, 8 July 1704, quoted in Stewart, History Vindicated, 95.

7 Session Book/Minutes, Presbytery of Wigtown, 8 July 1704, quoted in Stewart, History Vindicated, 95.

8 Session Book/Minutes, Presbytery of Wigtown, 8 July 1704, quoted in Stewart, History Vindicated, 96.

9 Session Book/Minutes, Presbytery of Wigtown, 8 July 1704, quoted in Stewart, History Vindicated, 96.

10 Session Book/Minutes, Presbytery of Wigtown, 8 July 1704, quoted in Stewart, History Vindicated, 95.

11 Monuments in Wigtown kirkyard, Scotland. See also the case of the Wigtown martyrs in Mark Jardine's website, Jardine's Book of Martyrs: History, the Covenanters, Scotland, accessed 9 February 2019, https://drmarkjardine.wordpress.com/2015/06/13/ the-wigtown-martyrs-who-condemned-the-women-to-drown-in-1685/.

12 By heterotopic I mean multiple coexisting, conflicting and disruptive meanings in use at any one given time.

13 Stewart, History Vindicated, 23.

14 M. Napier, The Case for the Crown in Re the Wigtown Martyrs Proved to Be Myths (Edinburgh \& London, 1863); Stewart, History Vindicated. See also Dr Mark Jardine, Jardine's website, Book of Martyrs, for multiple entries regarding Covenanters and 
conventicles at Wigtown, as well as those martyred, accessed 21 May 2018, https:// drmarkjardine.wordpress.com/.

15 Monique Scheer, "Are Emotions a Kind of Practice (And Is That What Makes Them Have a History)? A Bourdieuian Approach to Understanding Emotion," History and Theory 51 (May, 2012): 193-220, especially 193-94.

16 Scheer, "Are Emotions a Kind of Practice," 220.

17 Scheer, "Are Emotions a Kind of Practice," 220.

18 Scheer, "Are Emotions a Kind of Practice," 220.

19 See Laura Stewart, Rethinking the Scottish Revolution: Covenanted Scotland, 1637-1651 (Oxford: Oxford University Press, 2016); John Walter, Covenanting Citizens: The Protestation Oath and Popular Political Culture in the English Revolution (Oxford: Oxford University Press, 2017).

20 Agnes Mure Mackenzie, Passing of the Stewarts (London: Alexander Maclehose and Co., 1937), 254.

21 Archbishop Gilbert Burnet, Bishop Burnet's History of His Own Time (London, 1724-1734), quoted in David George Mullan, "Sharp, James (1618-1679)," DNB, https://doi.org/10.1093/ref:odnb/25211.

22 Mullan, "Sharp, James (1618-1679)."

23 Mullan, "Sharp, James (1618-1679)."

24 Alasdair Raffe, The Culture of Controversy: Religious Arguments in Scotland, 1660-1714 (Woodbridge, Suffolk: The Boydell Press, 2012), 35.

25 Mackenzie, Passing of the Stewarts, 254.

26 Act Against Preachers at Conventicles and Hearers at Field Conventicles, 28 April 1685, 1685/4/28, Records of the Parliaments of Scotland to 1707, ed. K.M. Brown et al. (St Andrews: University of St Andrews, 2007-2019), www.rps.ac.uk/mss/1685/4/28.

27 Argyll, Archibald Campbell, Earl of, (1629-1685), [A] Copy of the Last Speech of the Late Earl of Argyle; Delivered on the Scaffold, Who Was Beheaded at the Crosse of Edinburgh, (London, 1685), 1.

28 Argyll, [A] Copy of the Last Speech of the Late Earl of Argyle, 1.

29 Argyll, [A] Copy of the Last Speech of the Late Earl of Argyle, 1.

30 A Proclamation, for a Thanksgiving Throughout the Kingdom of Scotland, for the Late Defeat of the Kings Enemies (Edinburgh, 1685).

31 Naphtali, OR The Wrestling of the Church of Scotland for the Kingdom of Christ (n.p., 1667); Naphtali, OR The Wrestling of the Church of Scotland for the Kingdom of Christ (n.p., 1693).

32 Privy Council of Scotland, At Edinburgh, the twelfth day of December, one thousand six hundred and sixty seven. Whereas, there are many printed copies of a most treasonable and seditious pamphlet, entituled, Naphtali; or, The wrestlings of the Church of Scotland, lately imported, vended and dispersed within this kingdom, (Edinburgh, 1667).

33 [Alexander Shields], An Impartial Account of All Passages Relating to My Sufferings, Trials and Examinations, from the Beginning of My Imprisonment (Edinburgh, 1715).

34 Exhibition Card for 'Bible of field preacher, William Hannay of Tundergarth, Dumfiresshire', Q.L. 1994.1, Lent by the Church of Scotland, Covenanter Exhibition, National Museum of Scotland (NMS).

35 Exhibition Card for 'Bible of field preacher, William Hannay'.

36 Susan Karant-Nunn, The Reformation of Feeling: Shaping the Religious Emotions in Early Modern Germany (Oxford: Oxford University Press, 2010), 123.

37 David George Mullan, ed., Women's Life Writing in Early Modern Scotland: Writing the Evangelical Self, c.1670-c.1730 (Ashgate: Aldershot, 2003), 198-99.

38 Mullan, Women's Life Writing, 201.

39 Mullan, Women's Life Writing, 200.

40 Alec Ryrie, Being Protestant in Reformation Britain (Oxford: Oxford University Press, 2013), 39.

41 Ryrie, Being Protestant, 40. 
42 Ryrie, Being Protestant, 40.

43 James C. Coleman, Remembering the Past in Nineteenth-Century Scotland: Commemoration, Nationality, and Memory (Edinburgh: Edinburgh University Press, 2014), 135-53.

44 Gordon Pentland, Mark Nixon and Mathew Robert, "The Material Culture of Scottish Reform Politics c.1820-c.1884," Journal of Scottish History 32, no.1 (2012): 28-49.

45 Thorbjörn Campbell, Standing Witnesses: An Illustrated Guide to the Scottish Covenanters (Edinburgh: The Saltire Society, 1996).

46 Magnus Magnusson, Scotland: The Story of a Nation (2000; repr., Hammersmith, London: HarperCollins, 2001), 486.

47 Dolly MacKinnon, "'Correcting an Error in History': Battlefield Memorials at Marston Moor and Naseby," Parergon 32, no.3 (2015, Published 2016): 205-36, especially 208; Dolly MacKinnon, “'This Humble Monument of Guiltless Blood’: The Emotional Landscape of Covenanter Monuments," in Writing War in Britain and France, 1400-1854: A History of Emotions, ed. Andrew Lynch, Stephanie Downes, Katrina O'Loughlin, Themes in Medieval and Early Modern History (New York: Routledge, 2019), 161-81.

48 Mullan, Women's Life Writing, 197.

\section{Bibliography}

Adams, Sharon. "Wilson, Margaret (1666/7-1685), alleged covenanter martyr." In Oxford Dictionary of National Biography. Oxford: Oxford University Press, 2004, 10.1093/ref: odnb/29677.

Argyll, Archibald Campbell, Earl of, (1629-1685). [A]Copy of the Last Speech of the Late Earl of Argyle; Delivered on the Scaffold, Who Was Beheaded at the Crosse of Edinburgh. London, 1685.

Barnes, Timothy D. Early Christian Hagiography and Roman History. Tübingen: Mohr Siebeck, 2010.

Campbell, Thorbjörn. Standing Witnesses: An Illustrated Guide to the Scottish Covenanters. Edinburgh: The Saltire Society, 1996.

Coleman, James C. Remembering the Past in Nineteenth-Century Scotland: Commemoration, Nationality, and Memory. Edinburgh: Edinburgh University Press, 2014.

Jardine, Mark. Jardine's Book of Martyrs: History, the Covenanters, Scotland. https://drmarkjar dine.wordpress.com/.

Karant-Nunn, Susan. The Reformation of Feeling: Shaping the Religious Emotions in Early Modern Germany. Oxford: Oxford University Press, 2010.

Mackenzie, Agnes Mure. Passing of the Stewarts. London: Alexander Maclehose and Co., 1937.

MacKinnon, Dolly. “'Correcting an Error in History': Battlefield Memorials at Marston Moor and Naseby," Parergon 32, no.3 (2015): 205-36.

MacKinnon, Dolly. “"This Humble Monument of Guiltless Blood': The Emotional Landscape of Covenanter Monuments." In Writing War in Britain and France, 1400-1854: A History of Emotions, edited by Andrew Lynch, Stephanie Downes, Katrina O'Loughlin, 163-81. Themes in Medieval and Early Modern History, New York: Routledge, 2019.

Magnusson, Magnus. Scotland: The Story of a Nation. 2000 Reprint, Hammersmith, London: HarperCollins, 2001.

Mullan, David George, ed. Women's Life Writing in Early Modern Scotland. Aldershot: Ashgate, 2003. 
Mullan, George. "Sharp, James (1618-1679)." In Oxford Dictionary of National Biography. Oxford: Oxford University Press, 2004. 10.1093/ref:odnb/25211.

Naphtali, OR The Wrestling of the Church of Scotland for the Kingdom of Christ. n.p., 1667.

Naphtali, OR The Wrestling of the Church of Scotland for the Kingdom of Christ. n.p., 1693.

Napier, M. The Case for the Crown in Re the Wigtown Martyrs Proved to Be Myths. Edinburgh; London: Edmonton and Douglas, 1863.

Pentland, Gordon, Mark Nixon, and Mathew Robert, "The Material Culture of Scottish Reform Politics c.1820-c.1884.” Journal of Scottish History 32, no.1 (2012): 28-49.

Privy Council of Scotland. At Edinburgh, the twelfth day of December, one thousand six hundred and sixty seven. Whereas, there are many printed copies of a most treasonable and seditious pamphlet, entituled, Naphtali; or, The wrestlings of the Church of Scotland, lately imported, vended and dispersed within this kingdom. Edinburgh, 1667.

A Proclamation, for a Thanksgiving throughout the Kingdom of Scotland, for the Late Defeat of the Kings Enemies. Edinburgh, 1685.

Raffe, Alasdair. The Culture of Controversy Religious Arguments in Scotland, 1660-1714. Woodbridge, Suffolk: The Boydell Press, 2012.

Ryrie, Alec. Being Protestant in Reformation Britain. Oxford: Oxford University Press, 2013.

Scheer, Monique. "Are Emotions a Kind of Practice (And Is That What Makes Them Have a History)? A Bourdieuian Approach to Understanding Emotion.” History and Theory 51 (May 2012): 193-220.

Shields, Alexander. An Impartial Account of All Passages Relating to My Sufferings, Trials and Examinations, from the Beginning of My Imprisonment. Edinburgh, 1715.

Stewart, Archibald, History Vindicated in the Case of the Wigtown Martyrs. 1867 Reprinted. Edinburgh: Edmonston and Douglas, 1869.

Stewart, Laura. Rethinking the Scottish Revolution: Covenanted Scotland, 1637-1651. Oxford: Oxford University Press, 2016.

Thomson, J., ed. A Cloud of Witnesses. N.p., 1871.

Walter, John. Covenanting Citizens: The Protestation Oath and Popular Political Culture in the English Revolution. Oxford: Oxford University Press, 2017.

"Wigtown's Heritage." Created 2004, http://freespace.virgin.net/harold.hall/angchurch. htm.

Wodrow, Robert. The History of the Sufferings of the Church of Scotland from the Restauration to the Revolution. 2 vols. Edinburgh, 1721. 